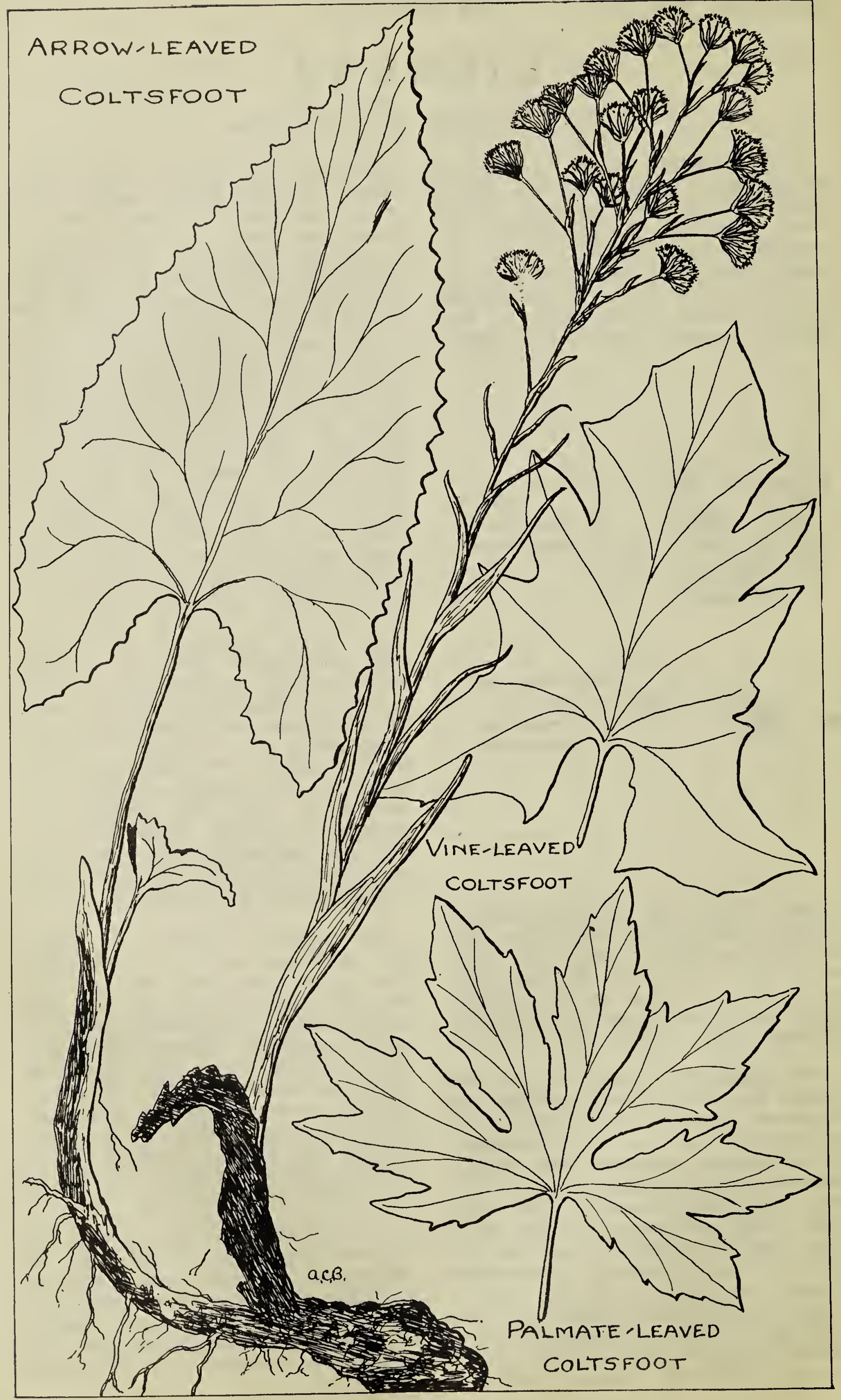




\section{The Coltsfoot in Saskatchewan}

\section{ARCHIE BUDD, Swift Current}

In Saskatchewan we have three species of Coltsfoot according to most authorities' concept of species. They belong to the genus Petasites, a word derived from the Greek petasos, meaning a covering for the head, originally given on account of the large basal leaves of some species. These plants have a peculiarity in that the flowering stem and generally the flowers appear in early spring before the leaves are produced. The leaves are all borne on long stalks from the crown of the root except the scaly, bract-like ones on the flowering stem. The inflorescence is almost entirely unisexual with the male and female flowers borne on separate plants. The flowering heads are generally whitish in colour, up to half an inch across, and soon bear fruit, each with a tuft of bristly pappus.

The most widely spread species is the Arrow-leaved Coltsfoot, Petasites sagittatus, which bears large, somewhat triangular leaves, from four to ten inches long, green or dull green above and white woolly below. These long stalked leaves are not lobed but are toothed along the mar- gins and are very conspicuous in moist spots, slough margins etc. of woodlands.

The Vine-leaved Coltsfoot, P. vitifolius, has somewhat similarly shaped leaves, but they are deeply lobed and generally not very white woolly on the underside. This species is fairly plentiful in wet spots and moist woodlands.

The third species is Palmate-leaved Coltsfoot, P. palmatus, sometimes called Woodland Coltsfoot, which is a species of the forest floor and has leaves palmately divided almost to the centre, and which are only white woolly beneath when very young. Some authorities place both the latter two species as varieties of $\mathbf{P}$. frigidus and call them respectively var. corymbosus and var. palmatus. They probably have good reason to do so but this changing and revising of the scientific names is somewhat disconcerting to the less technical folk. We, in the open south-western parts of the Province are not apt to find the Coltsfoot unless we go into the Cypress Hills, where all three species though scarce, are present.

\section{Fred Bard, Museum Director} (Continued from page 10)

humbly grateful to his predecessors for their endeavour, their patience and the store of knowledge he has gained from their guidance. Fred Bard is one of the best qualified field ornithologists in Western Canada and is recognized as such all over the country. The erection of the Provincial Museum of Natural History is the culmination of a dream that has grown with him during nearly 30 years.

$\mathrm{He}$ is an individual who finds the world is a beautiful place and one who has a tenderness for trees that are gnarled and unsymmetrical trees that, like people, have character and should be protected.

Apart from the Museum he has another project-Waterfowl Park, a field study station situated on Wascana Marsh south on McDonald Street in Regina. Twenty-five Canada geese find sanctuary there as do two beautiful whistling swans that were injured and have been nursed back to health. One of them will fly again but the other will never take to the air as it was injured by a gunshot wound in the leg.

In this park there is none of the artificiality of man's design, and Mr. Bard's main objective is to preserve the park in its natural state. At the present time Mr. Bard is in the process of producing a documentary film on the bird life of Wascana Marsh.

$\mathrm{He}$ does not lament the drain that the dream has been on his time and effort and is overwhelmed by the fact that the collections resulting from years of study and search, are now housed in permanent quarters.

The new Provincial Museum of Natural History stands as a monument to the perseverance, courage and devotion of such men as the three "Freds." Its administration is in good strong hands. 